\title{
PROBLEMS RELATING TO ARCTIC FARMOUT AND JOINT OPERATING AGREEMENTS
}

\author{
WAYNE G. HOLT*
}

\begin{abstract}
The form and content of Farmout Agreements and Joint Operating Agreements in use in the Canadian onshore oil and gas industry have become standardized to the point that the Canadian Association of Petroleum Landmen has published a Model Operating Procedure. Farmout and Joint Operating Agreements used in the Arctic require new concepts and different provisions and procedures to deal with the special problems caused by the demands of the environment and the requirements of the Canada Oil and Gas Land Regulations. This article examines the special environmental and regulatory problems of the Arctic, reviews the provisions of standard form agreements and suggests changes necessary to deal with Arctic problems, and discusses provisions and procedures peculiar to Arctic Farmout and Joint Operating Agreements.
\end{abstract}

\section{A. INTRODUCTION}

The Arctic is the new frontier in the ever expanding quest for new reserves of oil and gas in Canada. In May of 1971 there were eighteen drilling rigs at work in Arctic Canada, representing sixty-five per cent of exploratory drilling and forty-six per cent of all drilling activity in Western Canada. Of these eighteen rigs, three were at work in the Yukon Territory, eight were at work on the mainland of the Northwest Territories and seven were at work in the Arctic Islands. ${ }^{1}$ An eighth rig was being moved into the Arctic Islands. As many as thirty rigs were at work in the far North at the peak of the past winter's drilling activity.

The first well was drilled in the Canadian Arctic Islands as recently as $1962 .{ }^{2}$ In 1971 some twenty wells will be drilled in the Islands by at least four different operators. Plans are being made to drill the first wells in offshore areas of the Canadian Arctic, with actual drilling expected to commence in 1973 or 1974 . Recent events underlining the instability of supplies from the producing countries of the Middle East have added urgency to the need to explore the fringe areas of North America. The past few years have seen the beginning of exploratory drilling off the coasts of Canada, and the first real interest in exploring Arctic Canada, only recently regarded as an area for future exploration. The soaring demand for hydrocarbon energy in North America at a time when the security of overseas supplies has been placed in doubt has telescoped the future into the present. The technical problems and the cost of exploring the Arctic, remote from markets and environmentally forbidding, have assumed the proportions of difficulties to be overcome, rather than insurmountable obstacles, as the industry has expanded its search for oil and gas outward from the more accessible regions of the Continent.

The discovery of oil at Prudhoe Bay, in Alaska, and in the Mackenzie Delta region of the Northwest Territories, and the discovery of gas at Drake Point on Melville Island and on King Christian Island in the Canadian Arctic Islands, have given much needed encouragement

\footnotetext{
- Barrister and Solicitor, Panarctic Oils Ltd., Calgary, Alberta.

' Nickle's Daily Oil Bulletin, May 5, 1971, at 2, 6.

2 Dome et al Winter Harbour \#1, drilled on the southern shore of the Dundas Peninsula of Melville Island to a total depth of 12,541 feet, and abandoned in April of 1962.
} 
to these efforts. It would seem reasonable to assume that for the immediate future the industry can look for expansion at an accelerating rate in its exploration activity in the Arctic. In 1965 exploration expenditures in the North were twenty-three million dollars, while it is estimated that in 1971, one hundred sixty million dollars will be spent. ${ }^{3}$ Each year, a number of companies which have never before been involved in Arctic exploration are entering into this extremely costly venture. Whether these companies will assume the functions of the Operator in an Arctic joint venture or will be parties to an agreement under which another company will operate for them, it is important that they have a basic understanding of the major problems which the venture can expect to encounter. With this in mind, it is now appropriate and timely to review the difficulties encountered in an Arctic operation which are not experienced in a similar operation undertaken in Southern Canada, to examine briefly the effect that these difficulties may have on the concepts which have resulted in the evolution of the type of agreement in common use in Southern Canada, ${ }^{4}$ and to alert those who will be called upon to draft workable farmout and operating agreements for Arctic lands to some of the matters which ought to be considered in drafting such agreements.

\section{B. SOURCES OF THE PROBLEMS}

The problems encountered in an Arctic operation beyond those encountered in a similar operation elsewhere result from causes which can be discussed under two broad headings-the Environment, and the Regulations. It is of the greatest importance that the draftsman take both into account in proceeding with his task.

\section{The Environment 5}

The majority of the continental area of the North is treed, to a greater or lesser extent, and may be classified as sub-Arctic forest. Much of the coastal area and the more southerly of the Arctic Islands are devoid of vegetation except low-growing plants, including mosses and lichens, and can be classified as tundra. The majority of the Arctic Islands comprise a frozen desert, having less than two and one-half inches of precipitation a year. The terrain varies widely, from the mountains of the Yukon Territory on the west, through the lowlands and plateaus of the continent and the majority of the Islands, to the heavily glaciated mountains of Axel Heiberg Island which reach elevations of ten thousand feet and plunge into the deep fiords which border the entire Island and, in the extreme northeast, the mountainous spine of the Ellesmere folded belt, reaching elevations in excess of seven thousand feet capped by alpine glaciers. In the entire Arctic Islands area one could say that no soil, in the conventional sense,

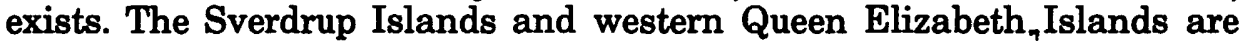
covered chiefly with fine sedimentary material locally derived from soft clastics. Glacially deposited material is rare, and largely confined to the western sides of the Islands bordering the Arctic Ocean on the northwest side of the Arctic Archipelago.

3 Address by A. H. Ross, President of the Independent Petroleum Association of Canada, given at the Pacific Northwest Trade Association Conference at Vancouver, B.C., on April 28, 1971.

- See, for example, the Canadian Association of Petroleum Landmen 1971 Form of Operating Procedure.

5 The writer is indebted to K. G. Alexander, Superintendent of Transportation, Panarctic Oils Ltd., for permission to use material from a paper presented by Mr. Alexander to the 1970 A.I.M.E. Pacific Southwest Mineral Industry Conference, San Francisco, May 27-29, 1970. 
The mainland endures a more extreme climate, with lower temperature and more precipitation, than the Islands. During the period from November through April, the Islands enjoy a dry continental climate, with little precipitation and little cloud, so that visibility is really obscured only by blowing snow or ice crystals. During this period the average temperature is lower than $-30^{\circ} \mathrm{F}$. The non-winter months of June, July and August are subject to heavy low stratus cloud and fog, due to the influence of open water, with temperatures generally about $+45^{\circ} \mathrm{F}$, occasionally rising to $+50^{\circ} \mathrm{F}$ and rarely to $+60^{\circ} \mathrm{F}$. The heaviest precipitation occurs during the months of September, October and November, with concentrated low cloud producing very hazardous flying conditions.

Except for a few local areas the entire waterway is frozen from October to mid-June. Annual ice thicknesses vary from fifteen to eighty inches, with landfast ice in the fiords normally eighty or ninety inches thick. The ice is normally best traversed in the daylight hours of late February through to May. From June to October the ice does not afford reliable support for heavy equipment, and travel over ice in the Arctic winter night, which lasts from November through February, is extremely hazardous. The break-up of sea ice is largely governed by temperature and cloud cover in May. Break-up reaches its maximum in the latter part of August, at which time shipping is normally scheduled into the Islands.

Cold weather in itself is not a serious problem, as modern technology has largely resolved the problems of men and machines working at low temperatures. The advantage of moderate precipitation is to some extent diminished by the winds which sweep freely over the low profile of most of the area, creating substantial drifts against objects projecting above the surface of the ground.

An Arctic operation depends upon air transport to a very large extent, and the Arctic environment hinders efficient air transport throughout much of the year. The best months for flying are March, April and May, when there is sufficient light, when the weather is not as severe as in the winter months, and when the ground is still frozen. During the summer months few Arctic airstrips are open, because in most places the thawed surface layer will not support heavy transport aircraft. On those runways that are dry enough for summer use, good natural sorting of sand results in very little cohesion between the grains, causing turbine aircraft to stir up clouds of sand and suffer serious abrasion by ingestion. A turbine engine which could normally go two thousand four hundred hours before requiring an engine change may have to go in for overhaul after only two hundred hours of summer operation. The autumn months between freeze-up and darkness endure flying weather so bad that efficiency depends on luck. The winter darkness prevents the establishment of a new air-supported operation. Established airstrips, equipped with proper lighting and navigation aids can be approached in the dark, but blowing snow is the limiting factor, reducing visibility to extreme limits on final approach.

Sea transport is limited by sea ice conditions. Much of the Arctic is open to navigation for only a very short time each year, the period from August 10th to September 10th being normally considered the optimum time, subject to local exceptions. During that period the ice is sufficiently well broken up to allow icebreaker escorted vessels to navigate in ice infested waters with up to forty per cent ice, and in some 
instances, along Lancaster Sound, ice-reinforced vessels can travel without immediate icebreaker support. If icebreaker support will be required, it must be arranged with the Ministry of Transport well in advance. Ice strengthened ships, especially tankers, are in very short supply and must be chartered very early in the year. Cargo must be discharged onto a beach, sometimes requiring the bulldozing of ground material to form a primitive wharf, and access is made difficult by land-fast ice and wind driven ice, which threatens the safety of the operation and piles up on the beach.

Overland transport is made difficult by the darkness of the winter months and the unstable ground conditions which prevail during about half of the daylight months. Tracked vehicles are utilized to cope with the ground conditions, but the efficiency of overland transport is so severely limited that air transport will normally be preferred.

\section{The Regulations}

The administration of Federal petroleum and natural gas rights has been divided between the Department of Indian Affairs and Northern Development and the Department of Energy, Mines and Resources; in broad terms, the former is responsible for predominantly land areas including the waters within the Archipelago, and the latter is responsible for offshore areas. ${ }^{6}$ The governing statutes are the Territorial Lands Act, ${ }^{7}$ which applies to Crown lands in the Yukon Territory and the Northwest Territories, and the Public Lands Grants Act, ${ }^{8}$ which applies to all Federal Crown lands, including lands within the provinces and offshore. The Canada Oil and Gas Land Regulations ${ }^{9}$ have been made pursuant to both Acts, and are at present under review by the Government. It is anticipated that amendments will be proposed, but indications are that the amendments will not affect Permits already issued under the present Regulations, ${ }^{10}$ or the conversion to lease of such Permits ${ }^{11}$ although the terms of Permits issued in the future will probably be considerably altered. Oil and Gas Land Order No. 1-1961,12 which was made under Section 58 of the Canada Oil and Gas Land Regulations, enabled the permittee to apply for leases of additional lands within a permit area after selecting leases under Sections $\mathbf{5 5}$ and 56. Land Order No. 1-1961 has been revoked, ${ }^{13}$ and it is anticipated that it will be replaced by provisions which will make the acquisition of additional leases more expensive to the permittee under both present and future Permits.

The administration and disposition of surface rights to Crown lands within the Yukon Territory and the Northwest Territories is governed by the Territorial Lands Regulations. ${ }^{14}$ The Government has proposed to implement environmental protection provisions under the Territorial Lands Act, ${ }^{15}$ which will govern land use operations in the Yukon Ter-

\footnotetext{
- Government Organization Act, 1966, S.C. 1966, c.25; Public Service Rearrangement and Transfer of Duties Act, R.S.C. 1970 , c. P-34; SOR/66-9.

7 R.S.C. 1970 , c. T.6.

- R.S.C. 1970 , c. P.29.

- SOR/61-253, as amended.

10 Ss. 30-54.

"Ss. 55-57, 60, 61 .

12 SOR/61-461.

${ }^{13}$ SOR/70-184.

11 SOR/61-1.

is Supra, n. 7.
} 
ritory and the Northwest Territories. These regulations, which in draft form $^{16}$ are described as the Territorial Land Use Regulations, will formalize and considerably restrict oil and gas operations, among others, in the Arctic. It is proposed in the draft regulations that between May 1st and October 31st any operation north of the 65th parallel of north latitude involving the use of explosives, vehicles exceeding 10,000 pounds gross vehicle weight, earth moving or land clearing equipment, drilling rigs, permanent camp establishment or road construction, will require written authority.

The draftsman of an Arctic agreement should be particularly aware of the provisions of the Canada Oil and Gas Land Regulations respecting permit deposits, ${ }^{17}$ expenditures ${ }^{18}$ and grouping, ${ }^{19}$ conversion to lease, ${ }^{20}$ obligation to lease, ${ }^{21}$ compulsory drilling under leases, ${ }^{22}$ and grouping of leases. ${ }^{23}$ Attention must also be given to the qualifications required to hold a Permit ${ }^{24}$ and the more restrictive qualifications required to hold a Lease, ${ }^{25}$ as well as the restrictions on transfers of Permits and Leases.26 The drafting of provisions which deal adequately with the permit deposit and grouping requirements is a particularly vexatious problem.

\section{Conclusion}

The difficulties posed by the environment and the requirements of the regulations dictate that every Arctic operation be well planned, and the planning must begin with the drafting of the agreement which will govern the operation throughout its life.

Armed with a basic knowledge of the major problems which an Arctic operation can expect to encounter, perhaps those responsible for drawing such agreements can approach their task in a more realistic way, and avoid the ire of those who find it impossible to carry out on the ground concepts which the draftsman found easy enough to set down on paper.

\section{FARMOUT AGREEMENTS-THE EARNING OF AN INTEREST IN ARCTIC LANDS}

The vast majority of the lands in the Canadian Arctic which are held by the industry are at present held under Permits issued under the Canada Oil and Gas Land Regulations. ${ }^{27}$ This paper will focus on the Permit as the basic document of title. Although many existing Permits will be required to be converted to Leases within the next three or four years, it is expected that lands held under Lease will present fewer problems for the draftsman than lands held under Permit.

The first thing that a solicitor drafting or reviewing an Arctic farm-

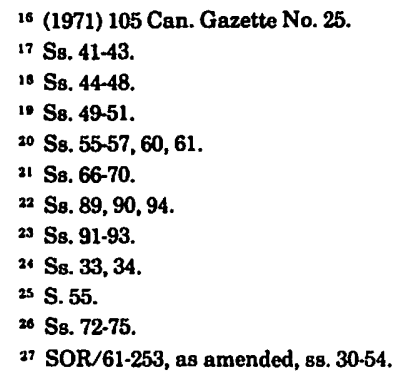


out agreement should ensure, in consultation with his company's operating personnel, is that the timing of the earning requirements as specified in the agreement is realistic, bearing in mind the restrictions imposed by the environment and the governmental authorities. Estimates of the length of time required to arrange the logistical support for an Arctic operation and then carry it through to a successful conclusion are almost invariably unduly optimistic, so the draftsman should allow more time to complete an operation of any kind than it would possibly appear to require.

\section{Geophysical Exploration}

Since the Arctic is a new and only slightly explored area, it is common in a farmout agreement to provide that a certain amount of geophysical work will be conducted prior to drilling. In establishing the time within which such work must be performed, regard must be had not only to the availability of crews experienced in Arctic work and the time required to move the crew and its equipment and support facilities to the area to be explored, but also to the short season suitable to the conduct of such work. The best conditions. for seismic work prevail in the period starting approximately April 1st and ending about September 15th. Unfortunately, during the greater part of this period conditions of ground instability are prevalent, and the proposed Territorial Land Use Regulations would require written authority to conduct most kinds of seismic operations between May 1st and October 31st. Heavy reliance has been placed upon the use of helicopters to transport shothole drilling rigs, recording cabs and camp buildings along the route of a seismic line. A seismic party equipped and supported in this way can achieve high production, but only at high cost. An Arctic seismic line costs approximately $\$ 3,500$ per mile, and consequently it is common to precede or accompany seismic surveys by gravity surveys to indicate areas of interest and guide selective seismic shooting.

It is necessary that those provisions of an agreement requiring geophysical work be fairly general. It is usual to provide merely that the farmee will conduct a specified number of miles of a specified kind of geophysical survey over specified Permits during a given year, rather than attempting to establish on a map exactly where the work is to be conducted or exactly what seismic lines will be shot. The high cost of geophysical work and the even higher cost of the exploratory drilling which the farmee will undertake on the basis of the results is sufficient to ensure that the farmee will be selective about the location and quality of the geophysical work.

The expense involved in moving a geophysical crew in and out of an area is such that as a rule Arctic crews are contracted for an entire season, or even two seasons. Unless the farmee already has a crew under contract for another operation in the North, or can obtain for the necessary time the services of a crew contracted to someone else and operating in the same general area, a small seismic program is not a practical requirement in a farmout agreement. Even if a crew is available it would not be economical to attempt a program of less than one hundred miles, except in the unlikely event that the crew was already located in the immediate area of the proposed work. If the farmee contracts for a new crew to move into the Arctic there will be 
very substantial mobilization and demobilization costs involved. Similarly, if the farmee obtains the services of a crew already in the Arctic and under contract to someone else, it would be normal to require that the farmee bear the cost of moving the crew to the farmee's area of operations and back to its original location or to some other location in the Arctic designated by the party making the crew available, as well as paying a proportionate part of the mobilization and demobilization costs of the crew. In addition, of course, the farmee would be expected to take over all responsibility for the crew while it was working for the farmee, as well as providing the necessary air and other logistical support for the crew during that time.

Since the period of time suitable for Arctic seismic work is short, parties having a crew under contract attempt to obtain full utilization of the time on their own projects. However, it sometimes happens that a program will be completed in less time than was planned, with the result that the crew has available unallocated time. In these circumstances it is possible to obtain the services of the crew for a small program, but normally crew availability would not be assured. The usual arrangement is that the crew will be made available if time permits, and this would not be satisfactory to the farmee who must be certain that an obligatory program will be completed on time. In some instances the farmor may have a crew under contract which could be made available to the farmee.

\section{Drilling}

The logistics of mounting a drilling program in the Arctic are, of course, more difficult than carrying out a geophysical program. The spud date established for a commitment well must take into account rig availability, whether the rig is already in the Arctic or must be moved in by air or sea, and the limitations imposed by the environment and the proposed Territorial Land Use Regulations on the movement of heavy drilling equipment. If the farmee plans to contract for a new rig, it may take six months to put together a suitable rig and make it ready for transport. Arctic rigs are designed to be transportable by Hercules transport aircraft or, in some cases, by large freight helicopters. It will sometimes be possible to move a helicopter transportable rig in summer to a previously prepared location, when ground conditions would not permit movement by Hercules, but generally the best time to transport a drilling rig by air is in March, April or May. Moving overland or by air and rigging up in the winter dark is very difficult and very costly, but if an airstrip and camp have been established in advance a winter air move can be made if necessary. If the rig is moved to the Arctic by sea, it will have to arrive in late August or early September. It will usually be necessary to unload the rig from the ship at an established port where there are suitable facilities, and then fly the rig to the first drilling location. The multi-stage shipping operation of moving the rig by rail to a port such as Montreal, then carrying it by sea to the Arctic, and then flying it to location at a time when the flying weather is at its worst will add to the cost and reduce efficiency to an extent which may eliminate the potential savings of sea tranpsort.

The costs involved in establishing a rig in the Arctic are such that long term drilling contracts are the rule. Most Arctic drilling contracts are for a term of two to four years and require the company contract- 
ing the rig to move it to the Arctic and, at the end of the contract, return it to Edmonton (or in at least one case, to Houston) or purchase it from the drilling contractor at a price established in the contract. The contract will normally include a footage rate, a day-work rate, standby with crew rate, a standby without crew rate, and in some cases a moving and rigging rate, a force majeure rate and a repair rate. Except under unusual circumstances, one or the other of these rates will be payable at all times during the term of the contract. A camp is also required, and will normally be provided by the drilling contractor at additional rates under the drilling contract. Catering services may be included in the drilling contract or may be provided by the company under a separate catering contract with one of the caterers operating in the Arctic.

If the farmee is able to take over the contract for a rig already in the Arctic, he will be able to commence drilling much earlier and will realize considerable savings. A combination of the farmee's need for the rig and the desire of the company having the rig under contract to avoid continuing liability for payments on a rig no longer required will determine what proportion of the rig mobilization and demobilization costs the farmee will be required to assume.

At the same time as the farmee is arranging for a rig to drill the commitment well, the preparation of the location must be proceeded with. It will normally be necessary to construct an airstrip, usually five thousand feet long and two hundred feet wide, and construction is usually undertaken in spring and fall, when the ground is neither frozen solid nor unstable. Again the restrictions to be imposed by the proposed Territorial Land Use Regulations must be kept in mind. An enormous supply of fuel for the rig, miscellaneous vehicles and support aircraft will also have to be established at the site. If the farmee does not have aircraft of its own for rig support, including transporting miscellaneous equipment, perishable foodstuffs and rig crews, arrangements will have to be made to charter suitable aircraft.

Since the Arctic Islands are for the most part a desert, water for drilling and normal camp uses is usually in short supply. Acccumulations of water at any time of the year are rare. Streams are usually full only during spring run-off and the few small lakes that exist freeze to the bottom in winter. In summer sea water is hauled overland for drilling, subject to the limitations imposed by ground conditions and the governmental authorities, and in winter snow melters are operated to meet both camp requirements and drilling requirements of over three hundred fifty barrels per day.

Once established, a drilling operation can normally be carried on throughout the year. The thawing of the permafrost around the rig in summer is effectively combatted by setting piles to support the rig or, more recently, by the use of styrofoam insulating mats under the rig.

Obviously, the solicitor drafting or reviewing an Arctic farmout agreement will have to give careful consideration to the problem of establishing the spud date for commitment drilling. In many cases it would not be unreasonable to expect to be allowed a year to commence drilling, perhaps longer if a geophysical program is to be carried out first to establish the exact drilling location.

The drilling capacity of the rig intended to carry out the commit- 
ment drilling must also be kept in mind in considering the maximum depth to which an obligation well is required to be drilled.

The cost of drilling in the Arctic is very high. After incurring formidable costs to bring a rig to the Arctic, ${ }^{28}$ the farmee must pay substantial drilling costs. ${ }^{29}$ In agreeing to fulfill the obligations under a farmout agreement, the farmee will have calculated as best it can the cost of meeting its commitments and the per net earned acre cost of the resulting land acquisition, and will have budgeted for the necessary funds. Few farmees will be so fortunate as to have sufficient unallocated funds available to substantially exceed the expense budgeted.

The usual substitute well clause found in a farmout agreement permits the farmee to abandon a well in which mechanical or other operational difficulties or impenetrable formations have been encountered above the specified contract depth, and requires the farmee after doing so to commence the drilling of a substitute well to contract depth within a limited period of time. It is submitted that the parties should give very careful consideration to the question of whether such a provision is required or reasonable in any particular Arctic farmout. If the farmor's position is that the objective of the farmout is to obtain a test of a specified formation at contract depth and that anything less will be of no value, perhaps the usual clause can be justified. In such cases, however, the farmee should at least be given a generous. period of time, perhaps six to nine months, within which to commence drilling the substitute well. The limitations of the environment and the restrictions imposed by governmental authorities may very well delay the resumption of drilling that long. The high cost of having a rig idle in the Arctic is sufficient incentive for the farmee to proceed as quickly as possible. The farmee should also be given considerable latitude in the location at which the substitute well must be drilled. It is suggested that it will usually suffice to say that the substitute well must test the same geologic structure as the well it replaces was intended to test. Incurring expenses of the magnitude involved in Arctic drilling, the farmee will be as anxious as the farmor to locate the substitute well as favourably as possible.

There are a number of alternatives to the usual substitute well clause that the parties should examine to cover a well which cannot be drilled on to contract depth because of mechanical difficulties or impenetrable formations.

Whether any of these alternatives are acceptable will be a function of the objectives the parties have in mind in undertaking the drilling. Each of these alternatives would require that the parties include in their agreement a stated amount representing the estimated maximum cost of drilling the test well to contract depth.

(a) The farmee could be given the right to abandon the test well and terminate the farmout agreement if it had expended the estimated maximum cost of drilling to contract depth without, in fact, reaching contract depth. The farmee would earn no interest

\footnotetext{
28 It costs $\$ 30,000$ to $\$ 40,000$ to truck a rig from Edmonton to Yellowknife and $\$ 300,000$ to $\$ 500,000$, depending on distance, rig size and the quantity of pipe required, to fly the rig from Yellowknife to a location in the Arctic Islands.

29 An average 10,000 foot well in the Arctic Islands would cost about $\$ 2,000,000$, dry hole cost, and would require about eighteen weeks to drill.
} 
in the farmout lands, but would incur no liability to the farmor for failing to drill to contract depth. ${ }^{30}$

(b) It could be provided that the farmee, having expended the estimated maximum cost of drilling to contract depth without reaching contract depth, could elect to abandon and earn only down to the depth drilled, and thereby be relieved of any further obligation to the farmor with respect to the drilling of that well.

(c) It could be provided that having expended the estimated maximum cost of drilling to contract depth without reaching contract depth, the farmee could elect to abandon and earn its full interest subject to the requirement that the farmee drill at its sole cost footage equivalent to that not drilled in the test well in a subsequent well drilled for the joint account.

(d) It could be provided that if the farmee had drilled deeper than a specified depth, less than contract depth, and had expended in doing so an amount in excess of the estimated maximum cost of drilling to contract depth, the farmee could abandon and would have discharged its obligation with respect to the drilling of the well and would have earned its full interest.

No doubt there are other possibilities.

The parties should also consider whether it might be reasonable to provide that if the farmee had expended the estimated maximum cost of drilling to contract depth without reaching contract depth and without encountering mechanical difficulties or impenetrable formations preventing further drilling, the farmee would have earned and the continued drilling of the well would be carried on for the joint account of the farmor and the farmee.

The point at which the farmee has fulfilled the drilling requirements of the agreement should be considered carefully. The extensive logistical preparation for drilling, including the construction of airstrips and wharfs, the establishment of a camp and the preparation of the location, are proper costs to the farmee of earning. It is submitted that the cost of production facilities is certain to be great, and largely unforeseeable at present, and that the farmee should not be required to bear the cost of such facilities. It is suggested that the farmee's obligation in a normal case should be to drill the well to contract depth, conduct such tests as are reasonable in the circumstances to establish the productive capability of the well, and abandon it or complete it through the wellhead. In cases where there is no reason to doubt the continued solvency of the farmee, it would seem reasonable to permit the farmee to defer actual completion of a potentially productive well until there is a market available for production. The investment in completion costs will be substantial, and there would normally be no objection to permitting the farmee to postpone the expenditure to a time when a more immediate recovery of the investment could be anticipated. The facilities which are likely to be required beyond the wellhead in order to take production would be extensive enough to warrant being the subject of a separate agreement when a market is available, in the same way that gas plants are now constructed and operated in southern Canada. Similarly, if an Arctic well is economic its productive capacity will be

so See, generally, Sychuk, Damages for Breach of an Express Drilling Covenant (1970) 8 Alta. L. Rev. 250; Ballem, Some Second Thoughts on Damages for Breach of a Drilling Commitment (1970) 48 Can. Bar Rev. 698. 
such as to make it impossible for the farmee to conduct the kind of production tests commonly required by the usual farmout agreement.

The Arctic is an area in which detailed understanding of the geology is just being developed and there is wide latitude for disagreement among experts as to geological merit and even as to the anticipated cost of drilling a well. It is submitted that it would be most difficult to establish damages for breach of a covenant to drill even if the cost of performance principle were applied, and that a liquidated damages clause $^{31}$ would be appropriate.

The usual type of farmout agreement contains a provision requiring the farmee to give the farmor notice of intention to test prospective formations and give the farmor the opportunity to be present to witness the test. It is suggested that the requirement of notice be deleted. The farmor will have been provided with a geological prognosis and drilling program before commencement of drilling, and should be able to correlate expected formations of interest with the daily drilling reports supplied by the farmee, and arrange to be at the wellsite at the appropriate time without notice. There are frequent delays in communication as a result of atmospheric conditions which interfere with radio communications, and delays in transportation are also encountered. The limitations of available camp space also dictate that the number of representatives that the farmor is entitled to have at the wellsite be restricted to one or two, and the farmor would normally be expected to supply transportation for its representatives and pay the cost of their accommodation in the Arctic.

\section{Default and Force Majeure}

The usual farmout agreement contains a default clause entitling the farmor to cancel the agreement should the farmee fail to remedy any default promptly after being given notice to do so by the farmor. It may be questioned whether such a provision is reasonable in an Arctic farmout, or in many others, for that matter. The farmee is obliged to carry out the obligatory work provided in the agreement in order to earn. The general default clause operates primarily to force the farmee to comply with lesser requirements, such as the obligation to supply the farmor with well information on a current basis. If so, the remedy would seem in most cases to be disproportionate to the evil it seeks to prevent. The case against a default clause is particularly strong when the farmout is based on a multi-well drilling commitment. It seems unreasonable that the farmee should be faced with the loss of wells already drilled as a result of some default of lesser magnitude than failing to perform its drilling obligations, and it is submitted that the agreement should at least provide for progressive earning as wells are drilled, with cancellation for default applying only to undrilled lands. The farmor would, of course, retain its remedies for breach of a covenant to drill.

The force majeure clause in an Arctic agreement should be drawn broadly, and in view of the judicial opinions expressed ${ }^{32}$ it would probably be wise to specify that delays due to weather or ground conditions, difficulties in marine transport or restrictions imposed by law

\footnotetext{
${ }^{31}$ Id.

32 Canada.Cities Service Petroleum Corporation v. Kininmonth (1963) 44 W.W.R. 392 (Alta. A.D.); affirmed on other grounds [1964] S.C.R. 439.
} 
or governmental authorities constitute force majeure. Although these difficulties are not unexpected in an Arctic operation and are, in that sense, foreseeable, they are not predictable with any degree of accuracy, and they very effectively shut down an operation. If the spud date for a commitment well has been realistically established in drawing the agreement it would be reasonable to exclude from the application of the force majeure clause the obligation to commence drilling, in any situation where that course appeared necessary. Certainly, if there is a definite object in having a test well commenced by the date specified in the agreement the parties could readily say so and exclude the application of the force majeure clause.

\section{Maintenance of Lands During Earning}

It is usual to provide in a farmout agreement that the farmee will bear the cost of maintaining the farmout lands in good standing from the date of the agreement to the date on which the farmee earns its interest. In jurisdictions where lands are maintained by cash payments this provision is simple enough to administer. While the same concept is applicable to lands held under Federal Permit, the mechanics are somewhat more complex and the agreement should be drawn to take into account the particular circumstances of the Permits involved in the farmout.

Under the Canada Oil and Gas Land Regulations deposits are required to be made in advance to secure the performance of the permittee's work obligations in the next ensuing permit period. ${ }^{33}$ These deposits are in the form of cash, bonds or promissory notes guaranteed by a chartered bank. ${ }^{34}$ If work in excess of that required by the Regulations is conducted the permittee accumulates work credits as a result of allowable expenditures ${ }^{35}$ which are applied in reduction of the deposits required at the beginning of subsequent permit periods. ${ }^{36} \mathrm{~A}$ drilling program may well generate sufficient work credits that the permittee's obligation to make deposits will be discharged by applying work credits for several successive permit periods and renewals.

The practice of the Government is to require that work credits be used to maintain a Permit when there are credits available for the purpose, and if credits are available the Government will not accept deposits to maintain the Permit.

Permits are normally grouped before any work is done, ${ }^{37}$ so that the work credits generated will be available for application to all the Permits in the group. ${ }^{38}$ Where Permits are grouped, work done on any lands within the group generates credits which are allocated to the group as a whole. The credits are not applied to any particular Permits within the group, but they may not be applied to any Permit outside the group. Groups may be terminated and Permits may be regrouped at will,39 but when a group is terminated all work credits accumulated by that group must be applied to specific Permits within that group, in any proportions the permittee desires. Once applied to a specific Permit,

\footnotetext{
3s $\mathrm{S} .41(1)$

34 Id.

3s Ss. 44-48.

36 S.43.

37 S.49.

38. 50 (1).

3.51.
} 
work credits must remain so applied and may not be transferred to any other Permit. ${ }^{40}$ If a Permit to which work credits have been applied is surrendered before all of the applied credits have been used in the maintenance of that Permit, the unused credit is lost.

If the farmor has done work on a Permit or on other Permits within the same group as a Permit forming part of the lands included in a farmout, the farmor may have accumulated work credits which are available to maintain the Permit, and the Government will require that the credits be used for that purpose. In this circumstance it will not be possible for the farmee to maintain the Permits comprising the farmout lands during the earning period. The parties will have to recognize in their agreement that the farmor's accumulated credits will be used for this purpose and make arrangements between themselves for the repayment by the farmee to the farmor of such credits.

When more than one party has an interest in a Permit, the Government requires all interested parties to designate an operator with whom the Government will deal exclusively in all matters pertaining to the Permit. The operator need not be the recorded owner of the Permit nor need he have any recorded interest in the Permit. The parties can, therefore, designate the farmee the operator of the Permits recorded in the farmor's name if they wish. Whether the parties choose to do so will depend upon the arrangements made between themselves with respect to maintenance of the Permits involved in the farmout and the right to group such Permits to take advantage of the work credits generated.

If the farmee holds no lands close enough ${ }^{41}$ to the farmout lands to be eligible to be grouped with the farmout lands, ${ }^{42}$ or if the parties have agreed that all work credits generated by the obligatory work performed by the farmee pursuant to the farmout agreement should accrue to the farmor, the farmor will remain the operator of the Permits comprising the farmout lands and will be given the right to group the Permits with lands other than the farmout lands in any way the farmor sees fit, subject to the requirement that sufficient credits be applied to the farmout lands to keep them in good standing while the farmee is earning its interest. The generation of sufficient credits for this purpose will discharge the farmee's obligation to maintain the Permits during the earning period.

If the farmee is to enjoy the use of credits generated by the obligatory work performed pursuant to the farmout agreement the farmee will be appointed operator and will be given the right to group the Permits comprising the farmout lands with other lands, subject to the requirement that sufficient credits be applied to the farmout lands to keep them in good standing while the farmee is earning its interest.

It is, of course, possible to take a position between these two extremes, with the parties agreeing that certain lands of each of them may be grouped with the farmout lands and that the requisite appointments of operator will be made to accomplish this end.

In some cases tne parties may think it desirable to provide that not only must sufficient credits be applied to the farmout lands to main-

$10 \mathrm{S.50}(2)$.

" S.49 (1).

42 The Government does not require that Permits be owned by the same parties in order to be grouped, as long as the same operator has been appointed for all Permits desired to be grouped. 
tain them during the earning period, but that sufficient credits must remain available to the farmout lands to maintain them for the next, or perhaps next two, succeeding permit periods or renewals. This would prevent the party having grouping rights from applying to other lands grouped with the farmout lands work credits resulting from allowable expenditures made on the farmout lands, in such a way that shortly after the farmee had earned its interest it would be necessary to make deposits to maintain the farmout lands because the surplus credits generated had been applied to other lands.

It may be that the farmor has not generated any work credits which can be used to maintain the Permits comprising the farmout lands, and that the farmout lands are being kept in good standing by deposits made by the farmor. In such cases it is usually provided that the farmee will replace the farmor's deposit with its own, and will make further deposits or apply work credits as required to maintain the Permits while the farmee is earning its interest. It is considered equitable that the farmee should have its own funds at risk during the earning period, and the fact that the farmee has made deposits with the Government operates as an additional assurance to the farmor that the farmee will duly perform its earning obligations under the farmout agreement. If the farmor were to make the deposits required to maintain the Permits while the farmee was earning its interest, the farmor would risk losing not only the benefit of the work to be undertaken by the farmee, should the farmee fail to perform, but also the deposits which the farmor expected to recover on the basis of such work.

Since the earning obligations which the farmee undertakes will normally substantially exceed in cost the deposits which the farmee may be required to make to maintain the farmout lands during the earning period, and since the farmor may be relying on the farmee's work to generate credits which will be available to maintain lands held by the farmor other than the farmout lands, the parties should consider whether the farmee should be required to post a bond guaranteeing performance of the work which the farmee has covenanted to perform. If the agreement contains a liquidated damages clause, it would be expected that the amount of the bond would coincide with the amount established as liquidated damages. In practice, the cost of performance bonds is so high as to be prohibitive, and instead the farmor is given a promissory note by the farmee, guaranteed by a chartered bank.

In summary, if the farmor has generated credits which are available for the purpose, they will be used to maintain the farmout lands, and the parties must provide in their agreement provisions by which the burden of maintaining the farmout lands during the earning period will actually be borne by the farmee. If deposits are used to maintain the farmout lands the farmee should provide such deposits.

\section{Insurance}

The usual farmout agreement will contain a clause requiring the farmee to carry certain insurance. ${ }^{43}$ It is submitted that an Arctic farmout agreement should require the following insurance to be carried by the farmee:

${ }^{43}$ See, generally, Sabey and Fingarson, Indemnity and Insurance Clauses in Joint Venture, Farmout and Joint Operating Agreements (1970) 8 Alta. L. Rev. 210 at 212. 
(a) Workmen's Compensation Insurance in accordance with all applicable laws. ${ }^{44}$ Any workmen not covered by such insurance should be covered by Workmen's Compensation in the Province in which they are ordinarily employed, which may be extended to cover workmen who are temporarily working outside the Province, ${ }^{45}$ or by Employer's Liability Insurance of at least $\$ 100,000$ per employee with an aggregate limit of $\$ 1,000,000$.

(b) Comprehensive General Liability Insurance, including unlicensed vehicles and extended to cover contractual liability, products and completed operations liability, owner's and contractor's protective liability, non-owned motor vehicles and non-owned aircraft, and including damage resulting from fire, explosion or blowout, but excluding subsurface damage, with limits of $\$ 1,000,000$ inclusive per accident or occurrence.

(c) Owned Motor Vehicles Public Liability Insurance with limits of $\$ 1,000,000$ inclusive.

(d) Owned or Leased Aircraft Liability Insurance, including Passenger Hazard Liability, with a single combined limit of $\$ 5,000,000$. Depending upon the type of aircraft used, this limit may be set higher or lower.

(e) If the farmee, rather than the drilling contractor, is responsible under the drilling contract for obtaining such insurance, All Risks (including blowout, fire and cratering) Physical Damage Insurance on drilling rigs, camps and appurtenant equipment in an amount equal to the full value thereof. The parties should also consider whether this insurance should cover transportation costs, so that the rig, camp and equipment are replaced in the Arctic.

(f) Wild Well Control Insurance with a limit of at least $\$ 3,000,000$ per occurrence, subject to the deductions and exclusions common to such insurance.

Other insurance which the parties may wish to consider would include the following:

(a) Insurance covering loss of or damage to material, equipment and supplies while in transit to or from or while located at the site of operations under the farmout agreement. The orderly stocking of supplies is essential to an efficient Arctic operation, and the loss of a shipment may be a severe blow to the entire operation. If supplies are lost while in transit by sea, it may be necessary to replace them by air. The parties should consider whether this sort of risk should be insured against, or whether the farmee can afford to be a self-insurer. This insurance is expensive, but in some cases may be justifiable.

(b) Seepage, Pollution and Contamination Insurance with a limit of $\$ 5,000,000$ per accident or occurrence. This type of insurance is almost prohibitively expensive when available, and most underwriters are not prepared to write this type of insurance at all. Although in most cases the parties will decide it is not practical to carry this type of insurance, they should at least consider it.

4 Section 3 of the respective Workmen's Compensation Ordinances of both the Yukon Territory and the Northwest Territories provide for Workmen's Compensation coverage by insurance, rather than by an as. sessment to maintain a fund. (Ordinances of the Yukon Territory 1966, 2nd session, c.1; Ordinances of the Northwest Territories 1967, 1st session, c.22).

45 E.g. The Workmen's Compensation Act, R.S.A. 1970, c. 397, s. 21. 
(c) Excess "Umbrella" Liability Insurance with a limit of at least $\$ 5,000,000$, with a self-insured retention of not more than $\$ 25,000$.

One or two additional matters deserve general mention. It will on occasion be necessary to charter cargo vessels or tankers to supply a large Arctic operation. The marine insurance normally carried by ship owners excludes navigation in Atlantic Coast waters north of $52^{\circ}$ North Latitude. A substantial additional premium will be charged to the charterer for Arctic navigation, ${ }^{46}$ and the insurance underwriters will normally restrict the voyage to a single Arctic port-of-call, or at most two closely located ports-of-call, and will require the vessel to be southbound by a specified date. It is usual to require an icebreaker escort beyond a stated point. In addition, the underwriters will impose a further increased premium or penalty if the vessel's Master does not have Arctic experience. Charterers should, therefore, require that the Master of the vessel have sufficient Arctic experience to avoid incurring such additional premium or penalty. It should also be kept in mind that the standard aircraft insurance policy in use in Canada excludes the North Slope area, which, as defined in the policy is in general the area west of $142^{\circ}$ West Longitude and north of the Arctic Circle.

\section{Governing Law}

Although the lands involved in an Arctic farmout will usually be situated in the Northwest Territories, most of the parties are likely to have their offices in Alberta. In these circumstances most parties would prefer to have the relationship created by the farmout agreement among themselves determined by Alberta law. Similarly, if disagreements among the parties must be litigated it would appear more convenient to carry on such litigation in Alberta. Since there will often be elements of the contract involving two or more jurisdictions, there is room for debate as to what law governs the contract and what courts have jurisdiction to adjudicate disputes. It is submitted that the convenience of the parties can best be served by including in the farmout agreement a clause providing that in the performance of the operations contemplated by the agreement the parties shall comply with the applicable laws, ordinances, statutes and regulations of the Northwest Territories and of Canada, but subject thereto the agreement shall be construed and the relationship of the parties shall be determined in accordance with the laws of the Province of Alberta, and that the courts having exclusive jurisdiction with respect to all matters relating to or arising out of the agreement shall be the courts of the Province of Alberta, which shall have capacity to adjudicate upon the application and interpretation of the laws of the Northwest Territories and of Canada applicable to operations conducted pursuant to the agreement.

\section{JOINT OPERATING PROCEDURES}

Many of the concepts which this paper has suggested should be applied to farmout agreements are also applicable, with appropriate modifications, to joint operating procedures. There are, however, a number of problems which are found only in operating procedures, and it is proposed to examine next the more significant of these problems.

16 For example, the additional premium quoted for a 1971 voyage of a tanker valued at $\$ 4,500,000$ with a single Arctic port-of-call is approximately $\$ 85,000$. 
There is no standard joint operating procedure, in the sense of a single form which has gained widespread industry acceptance. Nevertheless, there are more similarities than differences in the conceptual approach taken to the joint operation of petroleum lands in the majority of forms used by the industry. For the purposes of this paper the Canadian Association of Petroleum Landmen 1971 form of Operating Procedure will be used as an example of the modern type of operating procedure in use for a joint venture in Southern Canada. It is recognized that this form, like all others, has features that will not appeal to all draftsmen, but the ready availability of the form in the industry enhances its usefulness as an example.

\section{Definitions}

The draftsman must give particular attention to the definitions in the operating procedure and examine the context in which defined expressions are used. The definitions of "drilling costs" 47 and "completion costs"48 are particularly critical. The drilling of an Arctic well involves a great deal of advance preparation, including the acquisition and maintenance during drilling of the drilling site, roadways, airstrips, terminals, staging areas and such other similar facilities as may reasonably be required. After drilling an unsuccessful well there are the problems of restoration of the surface area occupied by such facilities, in addition to the abandonment of the well itself. There are also matters such as the cost of transporting personnel to and from the operations site and the cost of assembling, packaging, expediting and transporting material, equipment and supplies to and from the operations site, including costs incurred with respect to goods ultimately lost in transit. In considering an Authority for Expenditure ${ }^{49}$ the parties will want an estimate of the total cost of these substantial items. The definition of "drilling costs" could be extended to cover them. The parties would then have to consider whether such costs ought to be included in every case where the term "drilling costs" is used. For example, it could be argued that at least some of such costs should not form part of the "drilling costs" for the purposes of computing a production penalty on a successful independent operation ${ }^{50}$ because these costs do not represent money at risk in the usual sense of funds spent on drilling, and that such costs should properly be included with "equipping costs" 51 and "operating costs" 52 as a deduction from the gross proceeds of production rather than being included as drilling costs in the computation of the production penalty. On the other hand, it can be argued that these costs must be incurred as a normal part of the drilling operation and are just as much lost if the well is unsuccessful as are the funds expended for actual drilling. Further, "equipping costs" and "operating costs" will only be incurred if the well is successful, and so in a real sense are not risk costs, whereas the costs of the logistical support of the drilling operation must be incurred before and during the drilling of the well, with no assurance of success, and do represent funds at real risk. It is submitted that the more persuasive argument is that

\footnotetext{
47 Canadian Association of Petroleum Landmen 1971 Form of Operating Procedure, Clause 101(e).

4. Id. Clause 101(d).

49 Id. Clause 701(a).

so Id. Clause 1008.

${ }^{51}$ Id. Clause 101(f).

32 Id. Clause 101(j); Clause 1008.
} 
in favour of including logistical costs as drilling costs. Perhaps, to give the operating procedure a desirable measure of flexibility in this area, a definition of "logistical costs" distinct from "drilling costs" could be introduced and used throughout the operating procedure where appropriate to carry out the intention of the parties. It has been suggested earlier in this paper ${ }^{33}$ that the sort of facility which would give rise to "equipping costs" can be expected to be extensive enough to warrant being the subject of a separate agreement. It is submitted that the Operating Procedure should so provide, and that "equipping costs" should not otherwise enter into the operating procedure. This will involve redrawing the definition of "paying quantities"54 to ignore "equipping costs", which cannot justifiably be considered in the context of a single well, and to take into account an overall view of the prospects of marketing the petroleum substances discovered in the reservoir penetrated by the well.

It has not been necessary to date for the governmental authorities to prescribe spacing units in the Arctic. Since some of the provisions of the operating procedure assume that there is a definite area comprising a "spacing unit" 55 for any given well, there should be included in the definition of "spacing unit" a further provision providing that, if there is no such area allocated to a well by the applicable regulations, a spacing unit shall be deemed to be a section as defined in the Canada Oil and Gas Land Regulations.

\section{Change of Operator}

An Arctic operation involves start-up problems not usual in a similar operation undertaken in Southern Canada. There is justification for providing a longer period at the beginning of the operation when the Operator cannot be challenged. Perhaps the usual two year period ${ }^{56}$ should be extended to an initial term of three or four years, after which the right to challenge ${ }^{57}$ would revert to the usual two year interval.

The unfettered right to challenge the current Operator is the only satisfactory remedy for the dissatisfied party in a two party agreement, and the requirement that the new Operator remain in office for two years and absorb any costs in excess of those provided for in its challenge notice ${ }^{58}$ will give the current Operator, as the other party to the agreement, some degree of assurance that a challenge notice will not be issued impulsively. In a multi-party agreement it is submitted that, while the parties should each be free to issue a challenge notice, no party should be entitled to take over as Operator as a result of a challenge notice unless it can demonstrate to the satisfaction of the other parties that it has the necessary equipment and experienced personnel to operate efficiently. In an operating procedure in which provision is made for a management committee, ${ }^{59}$ it could be provided that the Operator be required to resign only upon the affirmative vote of the owners of a specified percentage of the participating interests

\footnotetext{
s3 Supra, at 459.

s4 CAPL Operating Procedure, Clause 101(m).

ss Id. Clause 101(q); Clause 1201.

56 Id. Clause 203.

s7 See, generally, Brown, Independent Operations, Obligatory Operations and Challenge of Operator Provisions in Joint Venture Agreements (1970) 8 Alta. L. Rev. 216 at 220.

ss CAPL Operating Procedure, Clause 203.

so See at 473, infra.
} 
of all parties other than the current Operator. It can be anticipated that in the Arctic the same Operator will operate a number of otherwise unrelated joint ventures, thereby achieving the economics of scale in each of such joint ventures with respect to logistical support facilities and equipment. The loss of these benefits to any of the joint ventures obviously should be included in estimating the monetary effect of a change of Operator. Because of the extensive support facilities involved in an Arctic operation there should be a period of at least six months allowed for a change of Operator as a result of a challenge or voluntary resignation.

\section{Duties of Operator}

The cost of operating in the Arctic is such that the Operator must be given fairly broad authority to make expenditures not previously authorized by the parties.60 A reasonable provision would be to allow an expenditure on a single undertaking of up to twenty-five thousand dollars, with the aggregate of such expenditures not to exceed fifty thousand dollars in any sixty dav period.

The limited camp accommodation available at an Arctic drilling rig requires that the Non-Operator's right of access to the operations ${ }^{61}$ be restricted to one or perhaps two representatives, and in an agreement involving a great number of parties it may be necessary that all of the Non-Operators be represented jointly by one or two designated people.

The usual "maintenance of leases" clause ${ }^{62}$ requires the Operator to do all things necessary to maintain the interest of the parties in the joint lands, except drill a well. Since Federal Permits may be maintained by work other than drilling, the exception in this provision should be broadened so that the Operator is neither required nor authorized under this clause to conduct any kind of exploratory work on the joint lands.

The insurance which should be carried by the Operator for the joint account will normally be substantially the same as that required of the farmee under a farmout agreement. ${ }^{63}$ In operating procedures providing for a management committee ${ }^{64}$ the parties could enjoy considerable flexibility in their insurance coverage by providing in the insurance clause only certain basic insurance coverage and authorizing the management committee to determine from time to time in light of cost, risk and loss experience what other or additional insurance should be carried for the joint account.

\section{Indemnity of Operator}

The draftsman should ensure that the risk of loss of material, equipment and supplies in transit to or from or while located at the site of the joint operations is borne by the joint account, not the Operator, if the Operator is carrying for the joint account the insurance which is required to be kept in force. It should also be clear that the Operator is entitled to charge insured losses to the joint account and credit the joint account with the insurance proceeds when the claim is settled.

\footnotetext{
6o CAPL Operating Procedure, Clause 301.

61 Id. Clause 307.

62 Id. Clause 309.

63 Supra, at 464

64 See at 473.
} 
The amount involved in an Arctic insurance claim is usually large, and the insurers are slow to settle the claim. It would not be reasonable to expect the Operator alone to carry the amount outstanding until payment is received from the insurers.

\section{Operator's Lien}

The operators lien clause of the CAPL 1971 Operating Procedure ${ }^{65}$ is a considerable advance over some of the older provisions in industry operating procedures, and should be quite suitable for an Arctic joint venture. For the present, the right to take an assignment of the proceeds of sale of the Non-Operator's share of petroleum substances ${ }^{66}$ will be of no benefit to the Operator. The provision for withholding information and privileges with respect to operations ${ }^{67}$ provides a real penalty in an area where all additions to previously accumulated information are valuable. The right of sale $e^{68}$ is obviously the most formidable penalty. It is submitted that the remedy of sale is preferable to the remedy of forfeiture which is found in some operating procedures. In an area where the value of the interest purported to be forfeited is largely unknown and may be wholly unrelated to the amount owed by the defaulting party, there is a great deal of latitude for the court to exercise its power to relieve against forfeiture. ${ }^{69}$ It is of the utmost importance that the parties involved in a joint venture know at all times what their respective participating interests are, and the introduction of a situation in which it is open to dispute whether the interest of a party has validly and finally been transferred to the other parties by forfeiture is undesirable. A sale of the defaulting party's interest, if properly and fairly carried out, should be viewed as neither a penalty nor a forfeiture, with the result that there would be no basis for the court to intervene. Presumably the sale would involve only as much of the defaulting party's interest as would be sufficient to recover for the other parties the amount in arrears, after deducting reasonable costs of the sale.

\section{Failure to Take Production in Kind}

The marketing of petroleum substances produced in the Arctic will be costly, and likely complex. In addition to having the right to market the share of a party who fails or refuses to take in kind its proportionate share of petroleum substances ${ }^{70}$ the Operator should be entitled to charge such party with all costs and expenses reasonably incurred in such marketing, including investment and a reasonable return on investment in capital facilities, where required.

\section{Independent Operations}

The basic mechanics of the independent operations clause in an Arctic operating procedure can be much the same as similar provisions in use elsewhere. ${ }^{71}$ It will be necessary to examine the distinction drawn

\footnotetext{
os Clause 504.

66 CAPL Operating Procedure, Clause 504 (b)(ii).

${ }_{67}^{67}$ Id. Clause 504 (b) (i).

68 Id. Clause 504 (b) (iii).

69 See, for example, The Judicature Act, R.S.A. 1970, c. 193, 8.32(o).

70 CAPL Operating Procedure, Clauses 602 and 603.

"Id. Article X.
} 
between a "development well" and an "exploratory well"72 to ensure that adequate recognition is given to the large size of the geologic structures being drilled in the Arctic. The four and one-half mile limit and the one mile limit provided in Clause 1002 of the CAPL Operating Procedure will also require consideration. Various time intervals will have to be extended ${ }^{73}$ to allow the time required to commence and complete a drilling operation in the Arctic. The parties may wish to consider whether the agreement should permit the proposal of a multiwell consecutive drilling program, to permit the efficient utilization of drilling equipment without delays between wells. Each well in the program would be conditioned upon the well preceding it being productive.

With respect to the party designated to conduct an independent drilling operation, ${ }^{74}$ it is submitted that the Operator should in all cases conduct the operation, even though the Operator is not participating in it. The reasons, no doubt valid elsewhere, why the Operator should not carry on an operation in which it is not participating ${ }^{75}$ would appear to be outweighed by the fact that the Operator is uniquely staffed and equipped to carry out the operation. Any party proposing to conduct an independent drilling operation in place of the Operator of the joint lands would almost certainly have to use the Operator's equipment, camps, airstrips and staging areas, attended by considerable inconvenience to both parties as well as insurance and other legal complications. Admittedly, there are problems in the approach suggested. Even if the parties participating in the independent operation provided the wellsite geologist and other key wellsite personnel, it is still virtually certain that the Operator will have access to information to which, as a non-participating party, it would not be entitled.

The problem of establishing a proper penalty for an independent operation is difficult in every operating procedure, and is even more serious in an Arctic agreement. The nature of the underlying problems has been discussed elsewhere. ${ }^{76}$ If the penalty is set too low, there will always be parties which, after considering the statistical probability of success in any particular operation, will invariably decide that they would prefer not to participate. If the penalty is set too high, it may operate as a virtual forfeiture of interest even where no such result is intended.

Geophysical exploration is common in the Arctic, as the parties endeavour to add to their knowledge of potentially favourable drilling locations. There is no really effective penalty in use in the industry with respect to independently conducted geophysical work. The type of penalty which requires a non-participating party to pay some multiple of what its share of the cost of the work would have been had it participated, in order to obtain the information and data derived from the work, ${ }^{77}$ does not prevent the non-participating party from simply waiting for the participating parties to propose a drilling location based upon their independent work and then joining them in the dril-

\footnotetext{
72 Id. Clause 1001.

${ }^{73}$ Id. Clauses 1002 and 1004.

7t Id. Clause 1005.

75 See Brown, supra, n. 56 at 219.

76 Id. at 218.

77 CAPL Operating Procedure, Clause 1012.
} 
ling of the well. A more effective penalty would provide that if a well is proposed to be drilled within the area covered by independently conducted geophysical work, each party desiring to participate in the drilling of the well which had not participated in the conduct of the geophysical work would be entitled to participate in the drilling only after paying a cash penalty with respect to the geophysical work. If any party which did not participate in the geophysical work also elected not to participate in the drilling of the well, a higher penalty with respect to the geophysical work would be added to the drilling penalty on the well.

The establishment of a penalty for drilling operations which will be equitable to both the participating and non-participating parties is made difficult by the present absence of detailed knowledge of the Arctic geology, and the inevitable time lag between the making of a discovery and the commencement of marketing. Considering the high risk nature of Arctic drilling, the deferred recovery of money invested in drilling while waiting for the development of markets, and the productive capability of a well which would be economic by Arctic standards, it is apparent that the usual type of production penalty will have no effect at all until production is marketed, and then will pay out rather quickly. To be of any value the penalty must represent a substantial multiple of what a non-participating party would have had to pay to participate in the well. A multiple often encountered is six hundred per cent, which compares with three hundred per cent often seen in Southern Canada. Allowing for the delay in marketing, the discounted present worth of a three hundred per cent penalty is clearly inadequate, and it may be in some areas that a six hundred per cent penalty would also be inadequate. For the present, at least, a penalty out of production is in many cases neither an effective incentive to participate in a proposed joint operation, nor an appropriate reward for assuming the risks of an independent operation.

A penalty which is undoubtedly more effective than a production penalty is an acreage forfeiture. It can be provided that a non-participating party will relinquish to the participating parties all interest in certain lands, expressed as a specified block of lands surrounding the well or as a group of lands comprising a certain area in the vicinity of the well, the exact lands comprising the area being specified by the party proposing to drill the well at the time of making such proposal. Alternatively, it can be provided that the non-participating party will relinquish to the participating parties a part of its participating interest in a stipulated area, according to some scale of values established in the operating procedure. Penalties of this type can be complicated by provision for horizontal division of the lands to which the penalty attaches. The argument against a land or interest forfeiture penalty, especially in the Arctic, is that it is an unknown quantity. The depth of sediments in the Arctic, particularly in the Sverdrup Basin, is such that a very substantial oil or gas field could be contained in a relatively small area. On the other hand, some prospective formations extend dozens of miles. When a party forfeits its interest, or part of its interest, in an area, it may give up an interest in an insignificant part of a major field or it may give up an interest in the entire field, depending to an unseemly degree on luck. A party may give up an interest out of all proportion to the value of the operation in which it failed to partic- 
ipate, and this notwithstanding that it may have previously participated faithfully in a long series of unsuccessful operations which, if only in a negative way, served to narrow the search for the location which ultimately proved to be productive. Normally, no forfeiture of interest penalty should apply if the independent operation is unsuccessful. There would be no production penalty in such a case, and there is seldom any justification for an acreage penalty to reward the participating parties for being wrong.

Considering all aspects, perhaps the fairest penalty would require the non-participating party to pay in cash forthwith upon completion of an independent drilling operation some multiple of what would have been its share of the cost of the operation had it participated, failing which the party would be subject to an acreage or interest forfeiture or a much higher penalty out of production. The clause could be drawn to include only one of such alternatives to a cash penalty, or it could permit the non-participating party to choose any one out of all such alternatives, or it could even authorize the participating parties to stipulate, upon completion of the independent operation, which alternative to a cash penalty would be available to a non-participating party with respect to that particular independent operation. In any event, it should be provided that only payment of the penalty in cash will obtain for a non-participating party its share of work credits generated by an independent drilling operation. The loss of work credits would operate as an additional incentive to the non-participating party to accept the cash penalty.

\section{Maintenance of Interest in the Joint Lands}

Reference has been made earlier in this paper ${ }^{78}$ to the difficulties encountered in the maintenance of Permits by the application of work credits or deposits. Normally, but not necessarily, the Operator of the joint lands will be the operator of the Permits and will be charged with the responsibility of keeping them in good standing.

The same principle as is applicable in the case of interests in joint lands which are maintained by cash rentals should prevail in the case of Federal Permits, with one significant modification. If a party has not surrendered its interest in a Permit pursuant to the surrender clause of the operating procedure it should be required to bear its proportionate share of the burden of maintaining the Permit, but the Operator should not be expected to advance the necessary deposit since it is not as simple to adjust the accounts of the parties when dealing with work credits, bonds or guaranteed promissory notes as it is when dealing with cash, and cash deposits are rarely used to maintain Permits. Reliance on the usual surrender clause could work to the prejudice of the Operator. Not having elected to surrender its interest in the Permit, a party would be required to share the burden of maintaining it. But if it in fact failed to do so what would be the result? Presumably that party would be in default and the Operator would have its lien. In the meantime, the Operator would have to take steps to meet the entire deposit due, to preserve the interest of the remaining parties. The defaulting party could belatedly put itself in good standing, retaining its interest in the joint lands. It is submitted that such a

73 Supra, at 461. 
result is inequitable to the non-defaulting parties, and that the Operator's lien is an inadequate remedy where the defaulting party has jeopardized the interest of all of the parties in the joint lands.

Since Permits are dated throughout the month, it is simpler from an administrative standpoint to maintain Permits by the month. It is suggested that the operating procedure should provide that every party, which has not given notice of the surrender of its interest under the surrender clause, is required to meet its share of the Permit deposit or credit requirements, and by the 15th of each month must have put the Operator in a position to maintain those Permits requiring deposits or work credits in the following month. This would be done by supplying the Operator with cash, bonds or a guaranteed promissory note, or an allocation of work credits, in the amount required for that party's share of the total requirement. If there are sufficient work credits available to maintain the Permits they will be applied by the Government for that purpose without regard to which of the parties, as among themselves, owns the credits. If there is an imbalance of credit as among the parties, provision will have to be made to resolve the problem between the parties concerned. Any party which fails to provide the Operator, by the 15th day of a month, with the means to meet the deposit or credit requirements of the following month should be deemed to have agreed to assign its entire interest in the Permits affected to those parties who do, in fact, meet the Permit obligations. Provision should also be made for an immediate registerable assignment giving effect to such principle.

Surplus credits can be carried forward without limitation under the present regulations. There is justification for a provision that each party will leave available sufficient of the credits generated by work on the joint lands to maintain the joint lands to the end of all the Permit periods and renewals, and perhaps some additional amount for allocation to Leases issued out of the Permits in reduction of rental. ${ }^{79}$ Certainly sufficient credits should be kept available for the next Permit period or renewal, or perhaps the next two periods or renewals. A joint operation may very well generate more credits than could ever conceivably be used to maintain the joint lands. The operating procedure should, therefore, contain provisions permitting each of the parties to nominate lands, in proportion to their participating interests, for grouping with the joint lands to obtain the benefit of surplus credits. If, on the other hand, there are insufficient credits available to maintain all of the joint lands, the grouping of the joint lands should be done with the concurrence of all parties, except in those operating procedures providing for a management committee.

\section{Management Committee}

The management committee is not a common concept in a joint operating procedure. An Arctic joint venture requires that a more or less continuous series of decisions be made by the parties, and in a multi-party agreement the decision making process can be considerably expedited by the appointment of a management committee. In an agreement involving only a few parties the management committee may consist of a representative of each of the parties, and may really be no more than a mechanism for formalizing the channels of communication

79 Canada Oil and Gas Land Regulations, 8s. 80-84. 
between the parties in the hope that the planning and decision making functions of the joint venture can be more efficiently conducted. In an agreement involving a considerable number of parties a management committee consisting of a separate representative of each of the parties might well be so cumbersome that its purpose would be defeated. In such cases the participating interests of the various parties should be reviewed, and provision made for parties having minor participating interests to appoint the same representative. It should be made clear that although some of the parties have a common representative, such representative acts and casts a vote for each of his principals separately. It is suggested that if such a provision is carefully drafted it should cause no difficulty to parties subject to the United States Internal Revenue Code. ${ }^{80}$

The authority of the management committee would probably include the following matters:

(a) consideration and approval of budgets; 81

(b) location and drilling program of wells drilled for the joint account;

(c) consideration and approval of proposals for exploration work, other than drilling, in excess of that required to fulfill the obligations of the parties with respect to work obligations on the joint lands;

(d) consideration and approval of proposals for exploratory work other than drilling required to fulfill the obligations of the parties with respect to the joint lands, and not included in an approved budget;

(e) selection of Leases out of Permits;

(f) removal of items from a previously approved budget;

(g) the creation of committees or subcommittees;

(h) approval of insurance to be carried for the joint account;

(i) establishment of rates of production for joint account wells;

(j) removal and replacement of the Operator;

(k) revision of rates in the Accounting Procedure; 82

(1) generally, all matters not specifically delegated to the Operator which pertain to operations for the joint account, other than those specified in (a) (b) and (c).

It would usually be provided that matters within items (a) (b) and (c) above would require the unanimous approval of all parties through their members on the management committee, while all other matters would be determined by the affirmative vote of a stated majority, determined by a combination of numbers and aggregate participating interests represented. The majority vote required will be established by analysing the participating interests of the parties. A possible choice would be something on the order of three or more parties owning together eighty-five per cent of the total participating interest of all the parties. ${ }^{83}$ The establishment of a management committee contemplates the inclusion in the operating procedure of the necessary mechanics for calling meetings and conducting votes. A modified form

\footnotetext{
so See Curran, American Tax Considerations in the Drafting of Canadian Joint Operating Agreements (1970) 8 Alta. L. Rev. 187 at 204.

s1 See at 475 , infra.

82 Id.

s3 It would be provided that in voting to replace the Operator the particpating interest of the current Operator would be disregarded.
} 
of the provisions in use in Unit Operating Agreements ${ }^{84}$ would suffice.

One of the primary duties of a management committee would be to approve a budget for the Operator. Provision should be made for the management committee to meet early in the third quarter of the year and work out a budget for the joint operations to be conducted in the following year. Approval of a budget should commit the parties to their participating interest shares of all items included in it, and should authorize the Operator to incur the expenditures provided for plus an overexpenditure allowance of perhaps ten percent. Items could be deleted from the budget by majority vote or the budget could be revised or added to by unanimous vote at any time, provided the Operator, as such, was not prejudiced by the change.

Considering the advance planning required for an Arctic operation and the high cost of any time which is wasted, there is much to be said for providing for an approved budget for the Operator even in those joint operating procedures which do not have a management committee.

\section{Sharing of Markets}

The various companies which are now active in the Arctic are illustrative of the divergent nature and size of the companies which are likely to be involved in Arctic operations in the foreseeable future. Some of these companies are international giants having marketing connections in Canada and internationally, both in North America and overseas. Others are relatively small and have no ready access to markets anywhere in the world. The transportation facilities required to move production out of the Arctic will be substantial in both size and cost, and the number of such transportation facilities will be limited. Considering the problems arising out of the ownship of the joint lands by the parties as tenants in common, ${ }^{85}$ a sharing of markets provision would seem to be equitable. The provision would not require the parties to market production as a single entity. Rather it would simply offer a solution to the problems which arise if some of the parties owning interests in a well have a market for their production and others do not. Such a provision might simply provide that any market available to a party shall be shared by it with the other parties, to the end that no party shall be obliged to store its share of petroleum substances produced except to the proportionate extent that all parties are obliged by lack of markets to store petroleum substances produced. Companies which are subject to the United States Internal Revenue Code would have to consider whether such a provision would cause them difficulty. ${ }^{86}$

\section{Accounting Procedure}

The biggest difficulty involved in the preparation of an Accounting Procedure for Arctic lands is the establishment of realistic overhead rates. There simply has not been enough experience in Arctic operations to date for operators to have learned what rates will reasonably reflect the cost of operating an Arctic joint venture. If there is a management committee which has been given the power to vary the rates provided

\footnotetext{
-4 See Article IV, Model Oil and Gas Unit Operating Agreement, approved at the 25th Mines Ministers' Conference, 1968.

ss See Olisa, Legal Problems Arising Out of Co-ownership of Oil and Gas Leasehold Estate and Facilities (1970) 8 Alta. L. Rev. 177; Rae, Equitable Sharing and End Use of Natural Gas (1969) 7 Alta. L. Rev. 429.

ses See Curran, supra, n. 79 at 198.
} 
in the Accounting Procedure, there is sufficient flexibility and the problem is less critical. If there is no such mechanism for adjusting the rates, the parties must build a mechanism for change into the Accounting Procedure. Two basic approaches to the problem seem to have been adopted.

Some Accounting Procedures provide for overhead rates which are a variable percentage of the cost of each type of operation, which in itself lends a degree of flexibility to the amounts chargeable by the Operator for overhead. Generally, it is also provided that the parties will reconsider the scale of percentage overhead rates periodically, and may by unanimous agreement make such changes as are warranted if the existing scale is insufficient or excessive.

A less desirable approach is to establish fixed overhead rates, coupled with a provision for periodic review by the parties and a provision for arbitration if the parties cannot agree. This type of Accounting Procedure often contains a statement of principle, presumably for the guidance of the arbitrators, to the effect that the parties have established the rates set out in the Accounting Procedure without the benefit of any experience which would indicate whether such rates are reasonable, and that the intent of the parties is that the Operator should neither gain nor lose by reason of carrying out the duties of that office.

It is suggested that the objective should be to key overhead to some variable which properly reflects the amount of time and supervision required of the Operator to carry out the operation to which the overhead charge pertains. There are a number of possibilities, including miles of program or number of shot points for geophysical work, number of wells or footage drilled for drilling operations, or the cost of or time involved in the particular operation. None of these will necessarily be proper in every case, but cost may well be the most appropriate standard over-all.

The adoption of some of the concepts previously proposed in this paper would necessitate the examination of some of the other aspects of the Accounting Procedure as well.

\section{E. CONCLUSION}

The Canadian Arctic challenges the ingenuity of those who would explore for new reserves of oil and gas to meet the energy hunger of the North American Continent. The operational and administrative problems are enormous, but by no means insurmountable. It is the task of the draftsman of farmout and operating agreements pertaining to Arctic lands to anticipate as many of these problems as possible and ensure that the governing agreement assists, rather than hinders, the satisfactory resolution of such problems. In undertaking this task the draftsman can obtain considerable guidance from the accumulated experience of the oil and gas industry in Southern Canada, but he must be vigilant that concepts evolved to resolve questions arising in areas of more mature exploration activity and less severe environment are not unthinkingly applied to an Arctic operation, where such concepts may be inapplicable. If the task is difficult and complex, it is also extremely interesting, and will no doubt be the subject of much debate in the years ahead. 